\title{
Prognosis of Workplace Bullying in Selected Health Care Organizations in the Philippines
}

\author{
Gloria M. Alcantara1 ${ }^{1}$ Eric G. Claudio² ${ }^{\text {, Arneil G. Gabriel }}{ }^{3 *}$ \\ ${ }^{1}$ Guidance Coordinator, College of Information and Communications Technology, Cabanatuan City, Philippines \\ ${ }^{2}$ International Linkages Office, Cabanatuan City, Philippines \\ ${ }^{3}$ Head Graduate School Research Department, Nueva Ecija University of Science and Technology, Cabanatuan City, Philippines \\ Email: ${ }^{\star}$ opats14@yahoo.com
}

How to cite this paper: Alcantara, G.M., Claudio, E.G. and Gabriel, A.G. (2017) Prognosis of Workplace Bullying in Selected Health Care Organizations in the Philippines. Open Journal of Social Sciences, 5, 154-174.

https://doi.org/10.4236/jss.2017.59012

Received: August 7, 2017

Accepted: September 15, 2017

Published: September 18, 2017

Copyright ( 92017 by authors and Scientific Research Publishing Inc. This work is licensed under the Creative Commons Attribution International License (CC BY 4.0).

http://creativecommons.org/licenses/by/4.0/

\section{c) (i) Open Access}

\begin{abstract}
The major objective of the paper is to determine the existence of workplace bullying in selected health care organizations in the Philippines. The approach used in the study is a mixture of qualitative and quantitative research methods. The findings show that a median range of score on six factors to workplace bullying was established. Results also found that: no significant relationship exists between demographic profile of participants and their diagnosis of workplace bullying. The statistical treatment of $\mathrm{t}$-test proved that there is no significant difference between the mean scores of the two groups as shown by a t-value of 2.02 in a two tailed test. The overall bullying prevalence scale is moderate as determined by individual responses of the participants. Human resource officers and organizational leaders may find the study useful in designing program intervention against workplace bullying. The implication of the study is the need for intervention program to prevent workplace bullying and revisit certain areas and policies where the degree of risk for frustration and dissents among medical personnel is high. The hospital managers must consider periodic review of personnel behaviour and policies as well as regular observation on bullying factors present in the organization to prevent its emergence. The study established the need to prevent bullying at its early stage to save organizational resources from wastage arising from workplace aggressive behavior.
\end{abstract}

\section{Keywords}

Workplace Bullying, Work Place Behavior, Health Care Organizations in the Philippines

\section{Introduction}

It is a dictum in organizational management that prevention is better than a cure 
[1]. Prevention saves the organization from unnecessary use of manpower and other precious assets needed to sustain strategic organizational development [2]; to cope with the fast pace of development in the external environment of an organization, fine tuning of the internal environment becomes necessary. Such internal adjustment may sometimes cause organizational paralysis arising from inappropriate use of technology, rat race competition or even lack of organizational agility [3]. The need of the organization to cope with the changes in outside environment may also lead to the emergence of workplace concerns and other negative organizational behaviors [4]. Among them are harassment, discrimination, work injuries, disability accommodation and workplace bullying. Workplace bullying as a form of aggressive behaviour is a concern both of the subordinates, and supervisors [5]. It is even argued that bullying is an endemic organizational pathology which may occur in all levels of organizations [6]. Thus organizations must have periodic and accurate prognosis to prevent its emergence and maintain a healthy and productive organizational environment [7].

Workplace bullying negatively impacted productivity [8]. It creates health problems among health care providers. According to Quine, maltreatment is common in health care institutions; even among doctors, medical students, and other medical personnel. The occurrence of bullying escalates in health care organizations. In general, there are three dimensions involved in bullying analysis among health care providers: attack upon competence, personal attack and attack through work tasks [9].

\subsection{Significance of the Study}

The significance of the study lies on the need to prevent bullying to save organizations from wastages in the use of its resources. Prevention of workplace bullying is preventing the loss and wastage of both precious human and material resources in the organization. In fact, based on studies, workplace bullying in health care institutions affects the health of employees their job satisfaction and patients care outcomes. And when it is left unchecked, it could result to: absenteeism, lack of productivity, various health problems, early retirement and/or resignation; and in general, lack of motivation to perform tasks. Workplace bullying dissipates material resources of the organization. Workplace bullying would cost high in terms of manpower resources, which incidentally considered as the most precious asset in every organization. Literature showed that bully environment could cost 4 billion dollars a year [10]. Also, as cited by Sheenan (1999) [11], bullying in Europe cost 4 billion Euro Dollars annually while Leymann in 1990, came up with an estimate of 30,000.00 to 10,000.00 US dollars as the cost of bullying at work. The amount accordingly is used to pay for bullying prevention activities and programs, consultancy and professional advices necessary for the organization to cope with problem on bullying.

Bullying for the purpose of this study is the presence of different factors in a work environment. The study, entitled "Prognosis of Workplace Bullying in 
Selected Health Care Organizations in the Philippines" is written to identify existence of factors which would likely create bullying environment among staff nurses and hospital administrators in a hospital setting. The study's theoretical and methodological significance together with its findings may help organizations in other context to consider scanning of its internal environment to determine the need for program intervention to combat workplace bullying. Finally, the replicability of the study in some other context regardless of the nature of the organization represents the paper's relevance.

\subsection{Theoretical Background}

Workplace bullying is a phenomenon caused by multi-causalities. Recent researches showed that the following are the factors associated to bullying at work: Perception of injustice in terms of promotion and performance evaluation [12]. If this factor is present, it demoralizes employees who are victims of unfair evaluation procedure and push the employees to unplanned resignation and leave the organization. Leadership style is another source of dissents and disappointments among employees especially when employees are not given enough room to decide and control their own work tasks. Where the organization is placed in a strong authoritarian leader, employees are bound to obey and to execute orders of the top echelon without consideration of the reality on the ground. This causes undue pressure and stress on the employees. In fact, it has been found out that there is a strong causal connection between stress and bullying as it was showed by Folkman, 2013 [13] and Delongis et al., 1999 [14]. According to them, "negative health effects result when an individual is bullied. Not to mention the dilemma that front line service providers had experience every time they are to implement policies that are not supported by adequate resources [15]. Moreover, the fast changing landscape in the organization and the dynamics of internal and external environments influenced the organizational interactions and internal work processes. The changing external rules and regulations by regulatory offices whether administrative or political, compel any organization to adapt to the fast changing trends. These external changes create internal micro-political dynamism which undermines the human face of personnel. According to Hoel and Salin [16], job insecurity and turn over are the results of bullying arising from organizational competition and structural changes. Workplace bullying is also a condition aggravated by organizational/environmental factors. For instance, the changing micro-political reconfiguration in the public health organization in US was known as one of the reasons for their failures [17]. Among employees, social grouping and interaction could create micro-organizational social norms and mores exclusive to the group members. This creates social exclusion on the worker not belonging to a group. Grouping is encouraged by all organizations. Human nature compels individuals to group with people with the same persuasions and interests. This leads to forming a sub-group within the organization having their group culture to the isolation of non members who possess different 
interests, work habits, views or ideas.

The presence of the six factors in the organization increases the likelihood of workplace bullying. In most hospitals where documents and reports are part of everyday performance of functions and its stressful environment arising from emergency cases of health care patients, the condition can easily develop. The common victims are the non managerial nurses. In fact the Nursing Code of Ethics foresees that "unethical behaviors such as workplace bullying must be reported through appropriate channels within the health care organizations or outside agencies if necessary, with the responsibility of ensuring safe workplace environment" [18]. The conceptual framework of the study is shown below;

Figure 1 presents the convergence of factors contributory to workplace bullying. The study adheres to the concept that the presence of many if not all of the factors in the organization as a result of its reacting to the external environment of competition may greatly influence the creation of conditions that may ripe into workplace bullying. All organizations operate as a system and reacting on the stimulus provided by its immediate organizational ecology, in that sense the internal changes within the organization if not managed well may lead to workplace bullying.

Meanwhile, the interrelatedness of variables of the study and how it was conducted can be gleaned from the paradigm (Figure 2).

The study is intended to measure the prevalence of workplace bullying in selected hospitals in Cabanatuan City, Philippines.

Specifically, the study is aimed at;

1) Describing the personal profile of managerial and staff nurses employed in private hospitals in Cabanatuan City in terms of:

a) Gender

b) Age

c) Highest educational attainment

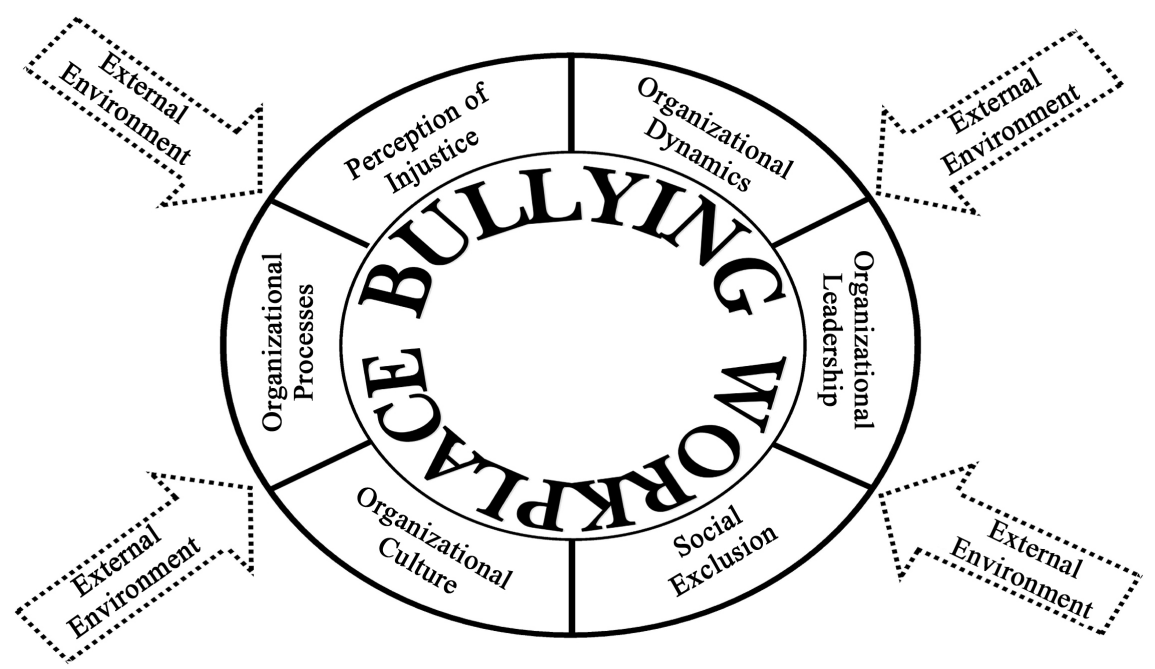

Figure 1. Conceptual framework for workplace bullying. 


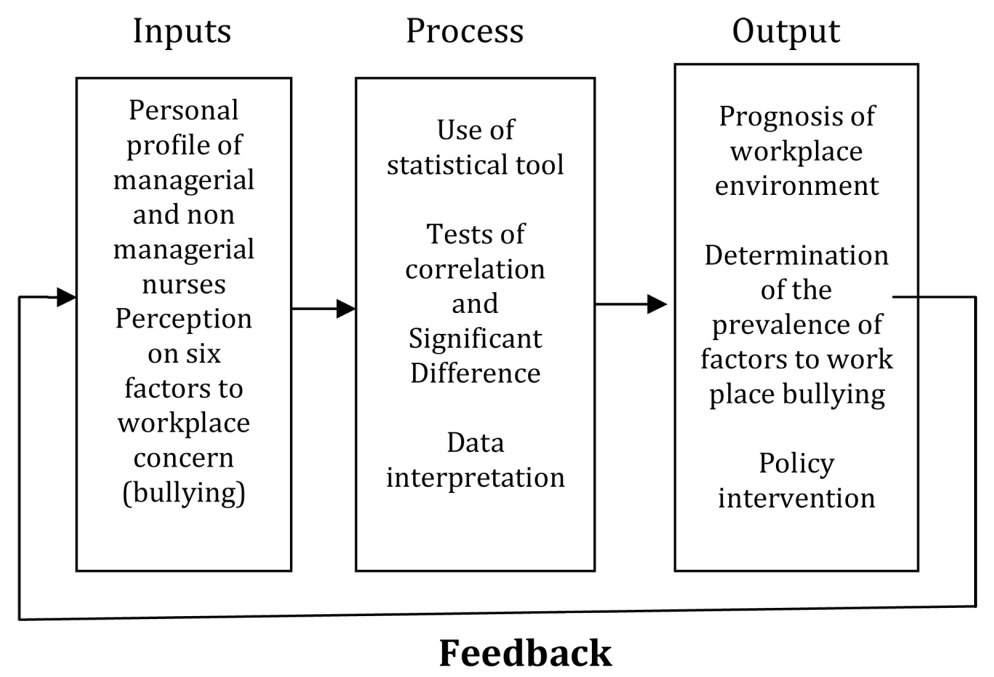

Figure 2. Research paradigm.

d) Number of years in service as nurse

2) Describing the perception of staff nurses and managerial nurses on the prevalence of factors antecedent to workplace bullying such as:

a) Perception of injustice;

b) Social exclusion;

c) Leadership style;

d) Prevailing Cultural Orientation;

e) Organizational Dynamics;

f) Organizational Processes.

3) Determining the relationship between the respondents profile and perception on the prevalence of factors antecedent to work place bullying;

4) Measuring the significant difference in the responses of staff nurses and managerial nurses;

5) To recommend program intervention to prevent workplace bullying.

\section{Methodology}

The study applied the qualitative-descriptive method of social research. It tried to describe the perception of hospital managers and staff nurses in five private hospitals in Cabanatuan City, Philippines. It is a qualitative study because it tried to draw insights on the perception both managerial and non managerial nurses on workplace bullying in which can be generalized in some other context or organization. The prevalence of factors on workplace bullying is measured by using a three Likert scaling technique verbally described as low, moderate and high prevalence. Determination of prevalence level is based on the general weighted mean generated from a survey questionnaires designed to measure participants' agreement on the presence of six factors of workplace bullying. Since the study involves human behavior in organization, a qualitative descriptive method is the appropriate research approach. It has the objective of showing "what is" or the existing phenomenon by defining, describing and interpreting bullying data with 
the end in view of putting up a pattern of behavior or ideas drawn from insights. It has the semblance of quantitative study as it requires the use of statistical interpretation and treatment to test the hypotheses and the statement of the problem. The sample of the study was determined after the application of the statistical treatment of Slovin's formula. There were 153 staff nurses and 30 managerial nurses who participated in the study. They are all healthcare providers working in five different hospitals.

The data were gathered using survey questionnaires developed and culled out from numerous literature on workplace bullying. The researchers personally distributed the questionnaires and retrieved the same after two days. The distribution of questionnaires was held on 5 - 10 March 2016. The retrieval rate of questionnaires was $100 \%$. Personal interviews and observation reinforced the survey results. Their responses were analyzed to establish whether there is a correlation between workplace bullying and their personal profile. It also determined the significant difference in the mean scores of the two groups of samples. The statistical test of central tendency and frequency distribution were used in so far as the demographic profile of the respondents is concerned. The statistical treatment of Pearson Product Moment Correlation was used to determine the acceptability or rejection of hypotheses. The questionnaire consists of three major parts. The first part consists of the personal profile of the respondents. The second part aims at looking into the presence of workplace descriptors antecedent to workplace bullying using the "lens" of the respondents, namely; 1) promotion injustice, 2) Perception of injustice; 3) social exclusion, 4) Leadership style, 5) Prevailing Cultural Orientation and 6) Organizational processes due to frequent changes in policy and rules. The level of prevalence was determined. The last part consists of whether there is significant difference between the responses of non managerial nurses and managerial nurses as well as the relationship between respondents profile and their perception of workplace concerns.

The study argued that the personal profile of the respondent nurses and managerial nurses are related to their perception of the existence of workplace bullying. And their responses on the survey questionnaires as measured, have no significant difference. Thus the following hypotheses are to be tested:

\section{Hypotheses}

Ho. There is no relationship between the respondents profile and their perception of factors antecedent to work place bullying.

Ho. There is no significant difference between the responses of staff nurses and managerial nurses.

\section{Results and Discussions}

\subsection{Demographic Profile}

\subsubsection{Age}

The demographic profile of the respondents is shown on Table 1. There are six 
Table 1. Respondents profile as to age.

\begin{tabular}{ccc}
\hline Age & Frequency & Percent \\
\hline 1) Age $21-30$ & 116 & 63.4 \\
2) Age $31-40$ & 47 & 25.7 \\
3) Age $41-50$ & 12 & 6.6 \\
4) Age $51-60$ & 8 & 4.4 \\
Total & 183 & 100.0 \\
\hline
\end{tabular}

personal attributes measured namely: age, gender, civil status, highest educational attainment and length of service. The survey result showed that in terms of age, the respondents are not equally distributed. There are 116 respondents aged 21 - 30 years old. While only 25.7 percent are belonging to age bracket 31 40. The study reveals that majority of health care personnel in Cabanatuan City are young professionals.

\subsubsection{Gender}

The gender of the respondents showed a larger number of female respondents compared to male. There are 107 female respondents while 76 males that took part in the study. The respondents are either supervisors or staff nurses. The result showed that as traditionally established, nursing as a profession remains female dominated.

Table 2 also indicates that when it comes to the acts of caring and love, women are more willing to share than men. Nursing as a profession is dominated by mothers, sisters or even daughters.

\subsubsection{Highest Educational Attainment}

The respondents are all College Graduates. The majority are bachelors' degree holders equivalent to $145 \%$ or $79.2 \%$ (Table 3). All are graduates of Bachelor of Science in Nursing and allied courses. Some of the respondents pursued higher level of education such as Masters' Degree with a total of $26 \%$ or $14.2 \%$ of the overall number of respondents. There are $6 \%$ or $2.2 \%$ doctorate degree holders of various health sciences and allied courses. Almost all the respondents are trained in nursing and medical related fields

\subsubsection{Length of Service}

Meanwhile, the length of service of the majority of the respondents is falling under the bracket less than two years (Table 4). They are newly graduates from the various Colleges of Nursing in the Philippines. At a young age, they are still lacking of experience but in terms of age they are in the prime of their lives. Meanwhile, almost half of the respondents have been working in the hospitals for two to five years. It reveals that majority of the participants are tenured health care workers. This is because the Labor Code of the

The Philippines mandates that any worker in a private organization working for more than 1 year shall be entitled to regular appointment. This is perhaps the 
Table 2. Respondents profile as to gender.

\begin{tabular}{lcc}
\hline \multicolumn{1}{c}{ Gender } & Frequency & Percent \\
\hline 1) Male & 76 & 41.5 \\
2) Female & 107 & 58.5 \\
Total & 183 & 100.0 \\
\hline
\end{tabular}

Table 3. Highest educational attainment.

\begin{tabular}{lcc}
\hline Highest Educational Attainment & Frequency & Percent \\
\hline 1) BS Nursing & 145 & 79.2 \\
2) MAN allied courses & 26 & 14.2 \\
3) Ph.D. & 4 & 2.2 \\
4) Others & 8 & 4.4 \\
Total & 183 & 100.0 \\
\hline
\end{tabular}

Table 4. Respondents Profile as to length of service.

\begin{tabular}{lcc}
\hline Length Of Service & Frequency & Percent \\
\hline 1) 1 - less than 2 years & 83 & 45.4 \\
2) 2 - 5 years & 90 & 49.2 \\
3) 5 - 10 years & 4 & 2.2 \\
4) 11 - 15 years & 6 & 3.3 \\
Total & 183 & 100.0 \\
\hline
\end{tabular}

reason why many of the staff nurses are not subject to workplace bullying.

The lowest number of respondents as to the length of service bracket is nine years and above considering that there are only two \% of them or four respondents. The table for personal profile is presented in Table 5.

\subsubsection{Perception of Injustice}

Table 5 presents the responses of the health workers on their perception of injustice in terms of promotion. The table indicates that,

In the eyes of the respondent-staff nurses and their superiors, there is system of promotion and the system is based on merit. This response is consistent with their disagreement of the system of patronage as the means to promote nurses. Both the managerial nurses and subordinates believe that there is fair system of promotion done periodically and open to all. The system of promotion is known to the nurses and is open to everybody. This fact is verbalized by the respondents as "strongly agree" having a weighted mean score ranging from $2.77-3.0$ for the item questions number 1, 6 and 8 . The finding negates the possibility of injustice in terms of promotion.

The finding is further confirmed by the "disagreement" that patronage and spoils are sometimes basis of promotion both in salary and administrative assignment. In most studies pertaining to workplace concerns, promotion is the common source of demoralization in ranks which later on leads to a hostile 
Table 5. Perception of injustice.

\begin{tabular}{|c|c|c|c|c|}
\hline $\begin{array}{l}\text { PERCEPTION OF } \\
\text { INJUSTICE }\end{array}$ & $\begin{array}{c}\text { Staff } \\
\text { Nurses }\end{array}$ & $\begin{array}{c}\text { Verbal } \\
\text { Description }\end{array}$ & Superiors & $\begin{array}{c}\text { Verbal } \\
\text { Description }\end{array}$ \\
\hline 1) Promotion on merit & 2.80 & Strongly Agree & 2.77 & Strongly Agree \\
\hline $\begin{array}{l}\text { 2) Promotion on } \\
\text { patronage }\end{array}$ & 1.17 & Disagree & 1.17 & Disagree \\
\hline $\begin{array}{l}\text { 3) There is a system } \\
\text { of promotion }\end{array}$ & 2.04 & Agree & 2.03 & Agree \\
\hline $\begin{array}{l}\text { 4) Promotion system is } \\
\text { observed }\end{array}$ & 2.18 & Agree & 2.17 & Agree \\
\hline $\begin{array}{l}\text { 5) There is periodic } \\
\text { performance evaluation }\end{array}$ & 2.00 & Agree & 2.00 & Agree \\
\hline $\begin{array}{l}\text { 6) Guidelines for } \\
\text { promotion is well } \\
\text { disseminated }\end{array}$ & 3.00 & Strongly Agree & 2.97 & Strongly Agree \\
\hline $\begin{array}{l}\text { 7) There is an } \\
\text { independent and } \\
\text { impartial selection } \\
\text { board }\end{array}$ & 2.00 & Agree & 2.03 & Agree \\
\hline $\begin{array}{l}\text { 8) Opportunity for } \\
\text { promotion is open to all }\end{array}$ & 3.00 & Strongly Agree & 3.00 & Strongly Agree \\
\hline Overall Weighted Mean & 2.27 & Agree & 2.27 & Agree \\
\hline
\end{tabular}

Legend: 1.00 to 1.66 Disagree; 1.67 to 2.33 Agree; 2.34 to 3.00 . Strongly Agree.

work place. In addition, work behavior is greatly influenced by work promotion. A person who does not deserve to be promoted when promoted invites dissent and job dissatisfaction [19]; other than this is a means to destruct attainment of employee's goals. As observed, there was indeed good promotional system in the selected hospitals in Cabanatuan City, Philippines.

\subsubsection{Social Exclusion}

As shown in Table 6, social exclusion is a factor to workplace concern. A person who is socially excluded fails to develop self confidence. Social exclusion is proven to lower moral and self-esteem. In the study, there is no policy or unwritten rule to separate staff nurses from their supervisors. This fact is shown by WM scores of 1.22 for staff nurses and 1.20 for managerial nurses. Both the scores obtained are numerical representation of "disagreement" to the statement that newly hired nurses are socially excluded from mingling with tenured or senior employees or supervisors. The answer is supported by consistent disagreement on item questions, 4, 7 and 8 where both supervisors and staff nurses have similar responses. This only goes to show that there is no conscious social exclusion in the workplace. The answers of both staff nurses and supervisors pointed to the fact that there is "disagreement" in terms of social exclusion which logically means that the organization allows and encourages socialization and social inclusion. The social and inter-personal processes in the hospitals or work places 
Table 6. Social exclusion.

\begin{tabular}{|c|c|c|c|c|}
\hline SOCIAL EXCLUSION & $\begin{array}{c}\text { Staff } \\
\text { Nurses }\end{array}$ & $\begin{array}{c}\text { Verbal } \\
\text { Description }\end{array}$ & Superiors & $\begin{array}{c}\text { Verbal } \\
\text { Description }\end{array}$ \\
\hline $\begin{array}{l}\text { 1) Isolation of newly } \\
\text { hired nurses }\end{array}$ & 1.27 & Disagree & 1.20 & Disagree \\
\hline $\begin{array}{l}\text { 2) There is diverse } \\
\text { groupings }\end{array}$ & 2.30 & Agree & 2.20 & Agree \\
\hline $\begin{array}{l}\text { 3) Lateral socialization } \\
\text { is promoted in the } \\
\text { organization }\end{array}$ & 2.33 & Agree & 2.30 & Agree \\
\hline $\begin{array}{l}\text { 4) There is grouping } \\
\text { based on seniority, } \\
\text { position and the like }\end{array}$ & 1.20 & Disagree & 1.27 & Disagree \\
\hline $\begin{array}{l}\text { 5) Work task is based } \\
\text { on specialization }\end{array}$ & 2.04 & Agree & 2.13 & Agree \\
\hline $\begin{array}{l}\text { 6) Socialization } \\
\text { programs are } \\
\text { sanctioned by the } \\
\text { administration }\end{array}$ & 2.79 & Agree & 2.80 & Agree \\
\hline $\begin{array}{l}\text { 7) Length of service is } \\
\text { the basis of work } \\
\text { assignment }\end{array}$ & 1.11 & Disagree & 1.10 & Disagree \\
\hline $\begin{array}{l}\text { 8) Groupings based on } \\
\text { skills is sanctioned by } \\
\text { the hospital }\end{array}$ & 1.15 & Disagree & 1.23 & Disagree \\
\hline Overall Weighted Mean & 1.77 & Agree & 1.78 & Agree \\
\hline
\end{tabular}

Legend: 1.00 to 1.66 Disagree; 1.67 to 2.33 Agree; 2.34 .

are not predetermined but is free to develop based on the employees behaviour and social preferences. It prevents isolation and alienation. The latter being factor to workplace bullying.

As a factor of workplace concern, social exclusion under items 1, 4, 7 and 8 showed that both supervisors and nursing staff believed that social isolation is not existing in the work place. The social groupings based on length of service, workload assignment based on seniority, isolation due to short length of service are not considered existing in the organization as a matter of practice. Social exclusion has the negative effect of poor performance [20]. Social exclusion is a form of work place harassment synonymous to "passing aggressive" [21]. It is negatively correlated to performance of hospitality workers [22].

Notice that all questions lead to one conclusion, that the absence of seniority in the workplace and its effect on social isolation on account of being new and non members of social group. It is observed that regardless of a person's length of stay in the area of assignment, workload remains equally distributed among staff nurses not to mention the equal treatment to employees regardless of their having disadvantage personal or work characteristics which by ocular inspection not a factor in treating staff nurses. On the contrary, among supervisors, they 
also believed and perceived that social exclusion is not practice in the organization as supported by a "disagree" response. And an average weighted mean score of 1.2 across number items.

\subsubsection{Leadership Style}

Table 7 below showed a non-directive and consultative behaviour as presented in numbers 1 and 4 items. The items for directive and non consultative behaviours showed a "disagree" response having a weighted mean scores of 1.15 and 1.10. This goes to show that both superiors and subordinate nurses believed that autocratic leadership is not present in the workplace. It is noteworthy here that having an authoritarian leader at work exerts pressures upon subordinate employees arising from demanding and autocratic control preference of superiors [23]. Such type of leadership can easily transforms organizational environment into a bully environment. Table 7 presented the item-responses of the participants.

Note that the two ideas are contradictory. If one is false the other is true. They are opposing questions. In general, the result showed that both subordinate nurses and their superiors are in unison to consider leadership style as liberal and democratic (results based, consultative, consensus oriented) free reign in the

Table 7. Leadership style.

\begin{tabular}{|c|c|c|c|c|}
\hline LEADERSHIP STYLE & $\begin{array}{c}\text { Staff } \\
\text { Nurses }\end{array}$ & $\begin{array}{c}\text { Verbal } \\
\text { Description }\end{array}$ & Superiors & $\begin{array}{c}\text { Verbal } \\
\text { Description }\end{array}$ \\
\hline $\begin{array}{l}\text { 1) Superior determines } \\
\text { when tasks are to } \\
\text { be finished }\end{array}$ & 1.15 & Disagree & 1.10 & Disagree \\
\hline $\begin{array}{l}\text { 2) Work flowchart for staff } \\
\text { nurses are present }\end{array}$ & 2.84 & Strongly agree & 2.77 & Strongly Agree \\
\hline $\begin{array}{l}\text { 3) Leadership is results } \\
\text { oriented rather than } \\
\text { process based }\end{array}$ & 2.11 & Strongly Agree & 2.13 & Agree \\
\hline $\begin{array}{l}\text { 4) Implementation of } \\
\text { policy without } \\
\text { consultation }\end{array}$ & 1.11 & Disagree & 1.10 & Disagree \\
\hline $\begin{array}{l}\text { 5) Consultation is part of } \\
\text { decision making }\end{array}$ & 2.68 & Strongly Agree & 2.70 & Strongly Agree \\
\hline $\begin{array}{l}\text { 6) Superiors tend to } \\
\text { prohibit rather exercise } \\
\text { liberal management style }\end{array}$ & 2.00 & Agree & 2.00 & Agree \\
\hline $\begin{array}{l}\text { 7) Meeting is free willing } \\
\text { and allows democratic } \\
\text { discussion }\end{array}$ & 2.77 & Strongly agree & 2.83 & Strongly agree \\
\hline $\begin{array}{l}\text { 8) Meeting threshes out } \\
\text { differences }\end{array}$ & 2.21 & Agree & 2.20 & Agree \\
\hline Overall Weighted Mean & 2.11 & Agree & 2.10 & Agree \\
\hline
\end{tabular}

Legend: 1.00 to 1.66 Disagree; 1.67 to 2.33 Agree; 2.34 to 3.00 Strongly Agree. 
management of results. They are characteristics of democratic model of leadership in the workplace which has implications to health care services. Abroad, many nurses are employed in public sector health care agencies. It is recognized that these public sector contexts can be characterized by authoritarian leadership that leads to the failures in the delivery of public health services and shows ineffectual responses against workplace bullying.

\subsubsection{Prevailing Cultural Orientation}

Culture is important in the organization. It provides motivation and cohesion to employees in terms of work target. It serves as basis for providing meaning to symbols, images, work ethics and work related values. The prevailing organizational culture determines to a great extent organizational policies that the members must observe and follow. Table 8 below shows that results of survey on work related values within the context of work ethics and organization culture. The result is clear as to the willingness of the organization to settle differences. Item number 4 speaks of structural and organizational desire to "settle disputes between and among members". The grievance machinery is intentionally created to provide avenue for settlement of differences. Both the staff nurses and superiors are "strongly agreeing" that groupings among employees are part of organization. It is an expression of the employees human nature where they socially interact with people of the same interest and persuasions. Needless to state, such human nature and tendency to associate dates back to the time of Greeks [24].

Also, both sectors in the organization believed that there is a functional grievance machinery to ensure speedy settlement of personal and work related

Table 8. Prevailing organizational orientation.

\begin{tabular}{lcccc}
\hline \multicolumn{1}{c}{$\begin{array}{c}\text { Prevailing Cultural } \\
\text { Orientation }\end{array}$} & $\begin{array}{c}\text { Staff } \\
\text { Nurse }\end{array}$ & $\begin{array}{c}\text { Verbal } \\
\text { Description }\end{array}$ & Superiors & $\begin{array}{c}\text { Verbal } \\
\text { Description }\end{array}$ \\
\hline $\begin{array}{l}\text { 1) Seniority is strictly } \\
\text { observed }\end{array}$ & 2.17 & Agree & 2.10 & Agree \\
$\begin{array}{l}\text { 2) Groupings are } \\
\text { observable in organization }\end{array}$ & 2.09 & Agree & 2.07 & Agree \\
$\begin{array}{l}\text { 3) There is grievance } \\
\text { machinery in placed }\end{array}$ & 2.77 & Strongly Agree & 2.73 & Strongly Agree \\
$\begin{array}{l}\text { 4) Groupings are } \\
\text { recognized and accepted }\end{array}$ & 2.93 & Strongly Agree & 2.90 & Strongly Agree \\
$\begin{array}{l}\text { 5) Administration } \\
\text { recognizes job well done }\end{array}$ & 2.15 & Agree & 2.17 & Agree \\
$\begin{array}{l}\text { 6) Harmony takes } \\
\text { precedence than efficiency }\end{array}$ & 2.08 & Agree & 2.13 & Agree \\
$\begin{array}{l}\text { 7) Legal conflicts among } \\
\text { co employees exist }\end{array}$ & 2.00 & Agree & 2.00 & Agree \\
$\begin{array}{l}\text { 8) Diversity in orientation } \\
\text { is very well managed }\end{array}$ & 2.00 & Agree & 2.00 & Agree \\
$\begin{array}{l}\text { Overall Weighted Mean } \\
\text { Avee }\end{array}$ & 2.27 & Agree & 2.26 & \\
\hline
\end{tabular}


disputes in the organization as shown by their "strongly agree" response. The mean scores for both items are 2.90 and 2.73 respectively. In general, the prevailing organizational culture is attuned to performance management and efficiency. It is compatible to creating work output while maintaining harmony as the center stage, front and priority of the organization. It is a typical Filipino organization where management is influenced by Filipino values of Pagkakaisa [25]. The organization is providing and recognizing the rights of employees to seek redress of grievances and pursuing all possible legal actions in proper forum to settle interpersonal legal complications. This observation is supported by a weighted mean of 2.0 both for staff nurses and their superiors verbally described as "agree".

In general, the organizational culture prevailing in the respondent hospitals is said to be healthy and conducive to professional and interpersonal development backed by management recognition that social groupings is a necessary human need in the workplace.

\subsubsection{Organizational Dynamics}

Meanwhile, organizational dynamism propelled by organizational changes can create bully environment. It provides undue pressures to the employees resulting in stress at work [26]. Changes in the organization to become effective must be coupled with corresponding personal and work related changes in attitude and ethics. The organizational dynamics is a result of the organization responsiveness to the internal and external environment. The study showed unity of perception among nursing staff and their superiors. The table below depicts the dynamism of the respondents' hospitals. As shown on Table 9, there is inconsistency in the responses of the staff nurses and their superiors. As one may notice, all the questions dovetailed to one thing, organizational dynamism as a result of quality of service upgrading and performance benchmarking. The inconsistency lies on question number 4 where the respondents across hospitals affirmed the fact that there is no on-going ISO accreditation. In general work pressures are the result of new process which requires extra-ordinary work performance of employees. Since there is no on-going accreditation local or international, as the employees revealed by a verbal description of "disagree", there is therefore a slight chance of changing processes and rules since there is no benchmark to meet coming from the accreditation or audit team. The benchmark is a natural offshoot of accreditation. Since little is the chance to establish and meet benchmark of performance due to lack of Accreditation and ISO application performance. The dynamics of processing and documentations in the workplace are presented in Table 9.

Noteworthy is the presence of some "rules and regulations that nobody can comply". It is verbally described by the respondents as "agree" by the superiors and staff nurses across hospitals. Rules that cannot be met is a source of stress and a potential bullying point on the part of a subordinate and is also prone to take advantage of by superior. It is in fact an obstruction of goal [27]. The 
Table 9. Organizational dynamics.

\begin{tabular}{|c|c|c|c|c|}
\hline $\begin{array}{l}\text { ORGANIZATIONAL } \\
\text { DYNAMISM }\end{array}$ & Staff Nurse & $\begin{array}{c}\text { Verbal } \\
\text { Description }\end{array}$ & Superiors & $\begin{array}{c}\text { Verbal } \\
\text { Description }\end{array}$ \\
\hline $\begin{array}{l}\text { 1) There are constant } \\
\text { changes in the way } \\
\text { reports and cases are } \\
\text { made }\end{array}$ & 2.29 & Agree & 2.23 & Agree \\
\hline $\begin{array}{l}\text { 2) There is an on } \\
\text { going reorganization }\end{array}$ & 1.80 & Agree & 1.77 & Agree \\
\hline $\begin{array}{l}\text { 3) there is little time to } \\
\text { submit reports } \\
\text { assigned by } \\
\text { administrators }\end{array}$ & 2.04 & Agree & 1.93 & Agree \\
\hline $\begin{array}{l}\text { 4) The hospital is } \\
\text { undergoing } \\
\text { accreditation for ISO }\end{array}$ & 1.14 & Disagree & 1.23 & Disagree \\
\hline $\begin{array}{l}\text { 5) Documentation for } \\
\text { accreditation is on } \\
\text { going }\end{array}$ & 2.19 & Agree & 2.17 & Agree \\
\hline $\begin{array}{l}\text { 6) New policies are } \\
\text { implemented from } \\
\text { time to time }\end{array}$ & 2.13 & Agree & 2.07 & Agree \\
\hline $\begin{array}{l}\text { 7) New methods and } \\
\text { processes are } \\
\text { introduced by the } \\
\text { regulatory body } \\
\text { (DOH) }\end{array}$ & 1.73 & Agree & 1.87 & Agree \\
\hline $\begin{array}{l}8 \text { ) The hospital is } \\
\text { bound by certain rules } \\
\text { and regulations } \\
\text { impossible to } \\
\text { comply to }\end{array}$ & 1.83 & Agree & 1.83 & Agree \\
\hline $\begin{array}{l}\text { Overall Weighted } \\
\text { Mean }\end{array}$ & 1.89 & Agree & 1.89 & Agree \\
\hline
\end{tabular}

respondents "agreed" on that point. The organization in general is undergoing process modification even without application for accreditation and as a whole experiences self-dynamism.

\subsubsection{Organizational Processes}

Organizational environment is a product of organizational processes, structures and procedures brought about by organizational dynamism [28]. In terms of organizational environment, the respondents across hospitals revealed that work pressures are manageable and therefore do not create unhealthy work environment. The responses undeniably show the existence of work pressures but work stress is not enough to create unhealthy organizational environment as in other organizations in some other industries. The question item numbers 4 and 5 are ordinarily provide accurate measures of workplace stress and perhaps bullying 
environment. As the table shows there is unequal distribution of work assignments among superiors and nursing staff. This however, seems to be accepted by workers. They "agreed" in the uneven distribution of work assignments but refused to state that there is stressful environment.

Another is the absence of adequate lighting system in the workplace. The respondents across hospitals showed that there is disagreement as to the presence of ventilation and lighting system in the workplace as revealed by a verbal description of agree and a WM score of 1.87 or "disagree" couched in the positive statement but responded in the negative terms.

The response therefore affirmed the fact that the need to have adequate lighting system and employee stress, as a result of workplace environment does not always go together. As the respondents showed, stress at work is not always a product of workplace hygienic factors.

However, the stressful condition of the organization is at median range of measurement. As the respondents "agreed" that stress is felt every hospital duty. The stress therefore as admitted by the respondents is caused not by the environmental hygienic factors but by the demands and pressures of work independent from the usual organizational provisions of machines and devices at work but by the nature of jobs and the pressure of serving hospital patients. Table 10 presents all the items under organizational environments having the results of

Table 10. Organizational processes.

\begin{tabular}{lcccc}
\hline $\begin{array}{l}\text { ORGANIZATIONAL } \\
\text { PROCESSES }\end{array}$ & $\begin{array}{c}\text { Staff } \\
\text { Nurse }\end{array}$ & $\begin{array}{c}\text { Verbal } \\
\text { Description }\end{array}$ & Superiors & Verbal Description \\
\hline $\begin{array}{l}\text { 1) Organizational } \\
\text { processes are stressful }\end{array}$ & 1.02 & Disagree & 1.00 & Disagree \\
$\begin{array}{l}\text { 2) Work pressure is } \\
\text { felt everyday }\end{array}$ & 1.27 & Disagree & 1.23 & Disagree \\
$\begin{array}{l}\text { 3) Employees take a } \\
\text { leave of absence } \\
\text { because of the } \\
\text { volume of work }\end{array}$ & 2.18 & Agree & 2.13 & Agree \\
$\begin{array}{l}\text { 4) Volume of work is } \\
\text { reasonably distributed }\end{array}$ & 1.13 & Disagree & 1.10 & Disagree \\
$\begin{array}{l}\text { 5) Workplace is well } \\
\text { ventilated and lighted }\end{array}$ & 1.91 & Disagree & 1.83 & Disagree \\
$\begin{array}{l}\text { 6) Employees are } \\
\text { happy }\end{array}$ & 2.00 & Agree & 2.00 & Agree \\
7) Planned work \\
$\begin{array}{l}\text { activities and given } \\
\text { enough time to finish }\end{array}$
\end{tabular}

Legend: 1.00 t 1. Legend: 1.00 to 1.66 Disagree; 1.67 to 2.33 Agree; 2.34 to 3.00 Strongly Agree. 
the absence of stressful environment, WM of 1.1 or disagree; 1.25 as to the work pressure or disagree; the tendency to file a leave of absence because of the volume of work, 2.15 or agree; employees are jolly and cheerful, WM of 2.00 or agree, and work activities are planned and assigned sufficient time to finish except in case patients' emergency 1.12 or disagree. The table that follows showed the other results of survey questionnaires across private hospitals in Cabanatuan City in so far as perception on organizational environment and processes are concerned.

\subsubsection{Measure of Prevalence of Workplace Bullying (Non Managerial Nurses)}

Table 11 presents the measure of prevalence of workplace bullying on the perception of nursing staff. As the table shows the adjectival rating of the overall weighted mean score is moderate prevalence. For the non managerial nurses, the presence of workplace bullying is moderate as shown by a 2.083 weighted mean score. Cultural orientation and perception of injustice in promotion have the high degree of prevalence

Table 12 provides the responses of managerial nurses. The factors of perception of injustice and cultural orientation have the high degree of prevalence among workplace bullying factors. Other factors have moderate prevalence on the eyes of the managerial nurses. The data showed that the two groups of samples

Table 11. Measure of prevalence of workplace bullying (non managerial nurses).

\begin{tabular}{lcc}
\multicolumn{1}{c}{ Factors } & Weighted Mean & Measure of Prevalence \\
\hline 1) Perception on Injustice & 2.27 & High \\
2) Social Exclusion & 1.77 & Moderate \\
3) Leadership & 2.11 & Moderate \\
4) Cultural orientation & 2.77 & High \\
5) Organizational Dynamics & 1.89 & Moderate \\
6) Organizational processes & 1.69 & Moderate \\
Overall Prevalence & 2.083 & Moderate \\
\hline
\end{tabular}

Table 12. Measure of Prevalence of workplace bullying (managerial nurses).

\begin{tabular}{lcc}
\multicolumn{1}{c}{ Factors } & Weighted Mean & Measure of Prevalence \\
\hline 1) Perception on Injustice & 2.27 & High \\
2) Social Exclusion & 1.78 & Moderate \\
3) Leadership & 2.10 & Moderate \\
4) Cultural orientation & 2.26 & High \\
5) Organizational Dynamics & 1.89 & Moderate \\
6) Organizational processes & 1.66 & Moderate \\
Overall prevalence & 1.99 & Moderate \\
\hline
\end{tabular}


have almost the same perception on the prevalence of workplace bullying in selected health care organizations in the Philippines. The overall weighted mean score is 1.99 verbally described as moderate prevalence.

\subsubsection{Prevalence of Workplace Bullying Managerial Nurses}

Significant The personal profile and workplace perception of respondents is shown on Table 13. As it is shown, there is no relationship between age and workplace perception of participants. The Significant relationship between the respondents profile and perception of bullying factors shows that there is enough statistical evidence to prove that a negative correlation is established using statistical correlation which is equal to -0.077 having a $P$ value of 0.299 at 0.05 significant value. This means that a weak correlation is revealed between profile variables and their perception of workplace bullying. The same statistical interpretation was arrived at other profile variables. Therefore, there is no significant relationship between profile variables and workplace concerns making the study accept the null hypothesis.

\subsubsection{Significant Relationship between Profile and Workplace Bullying} There is sufficient statistical evidence to prove that there is no significant difference on the responses of staff nurses and supervisors on their organizational diagnosis of Factors antecedent to workplace bullying in private hospitals in Cabanatuan City, Philippines. Using a two tailed test, superiors and nurses showed a critical 2.02 mean score showing that the null hypothesis on the absence of significant difference between the two groups of samples is accepted (Table 14).

\section{Summary, Conclusion and Recommendation}

The factors of perception of injustice and cultural orientation have the high degree of prevalence among workplace bullying factors. This finding is based on

Table 13. Significant relationship between respondents' profile and workplace bullying.

\begin{tabular}{cccc}
\hline Profile & Workplace, r-value & p-value & Verbal Description \\
\hline Age & -0.077 & 0.299 & No significant relationship \\
Gender & 0.050 & 0.501 & No significant relationship \\
Civil Status & -0.014 & 0.849 & No significant relationship \\
\hline
\end{tabular}

Significant difference in the responses between the two groups of sample population.

Table 14. Significant difference in the responses between the two groups of samples.

\begin{tabular}{|c|c|c|}
\hline Difference & Staff Nurses & Superiors \\
\hline Mean & 2.002 & 1.994 \\
\hline Variance & 0.003 & 0.003 \\
\hline $\mathrm{N}$ & 183 & 30 \\
\hline t Stat & \multicolumn{2}{|c|}{$0.84 \mathrm{~ns}$} \\
\hline t Critical two-tail & \multicolumn{2}{|c|}{2.02} \\
\hline
\end{tabular}

Ns = no significant difference. 
both the perception of managerial and non managerial nurses distributed as 153 for non managerial and 30 for managerial nurses. The study showed that there is fairness in the promotional system but there is high prevalence of bullying in promotion. There is also no known social exclusion creating isolation among and between staff nurses and superiors themselves. A liberal democratic style of leadership has been established and grounded on consultation and democratic processes like meeting deadlines by means of consensus building. The cultural orientation of both groups of respondents across private hospitals in Cabanatuan City is also conducive to work performance but have the high prevalence rating both in the eyes of the non managerial and managerial staff nurses. A grouping of personnel is established but not in terms of social exclusion but in terms of organizational structural location of nurses in the hierarchy. Such a finding is common and natural because organization structure is based on relative position in the organization and job description. The dynamism of the organization is maintained and created without unnecessary pressure on the organizational environment.

The study showed that there is no relationship between personal profile of the respondents and perception on workplace bullying. There is also no significant difference between their responses and perception of staff nurses and managerial nurses. Thus the null hypotheses are accepted.

However, the response that some rule is implemented without "the means to comply" is a concern that must be looked into. It is a potential source of workplace bullying. Work is "unfairly distributed" and the source of stress is the nature of job rather than internal environment of the organization. The study also showed that both the null hypotheses are accepted considering the sufficiency of statistical evidence to support the findings. There is also enough statistical evidence to prove that there is no significant relationship between respondents' profile and perception on factors antecedent to work place bullying.

\section{Recommendations}

The study showed that selected health care institutions in Cabanatuan City Philippines are generally free from workplace bullying. But prognosis showed emergence of some high prevalence of factors leading to workplace bullying is possible. Thus the following recommendations are submitted:

1) There is a need to legislate on workplace bullying in the Philippines. The lack of statute dealing exclusively to workplace bullying leads to uneven understanding on the issue. A nationwide measurement of factors to workplace bullying may evenly distribute citizens understanding of the issue. The Organizational dynamics of the hospitals are seemingly caused by its internal processes and not by ISO application. Apart from stressful environment caused by the changing policies brought about by external environment, changes are inherent in the respondent organizations. This therefore requires that administrators must strictly monitor the process and its concomitant organizational response as they 
may create an environment where stress level becomes unmanageable. The Dynamics of the organization when coupled with the perception that work is "unfairly distributed" may serve as a fertile ground for workplace bullying.

2) The issue raised that certain rule "cannot be complied with" must be revisited. Any policy imposed but avenues for compliance is not possible is bullying in itself. The frustration that it may cause to those who wish to comply but failed to do so for lack of "means" to comply is a cause of dissatisfaction.

3) The "unfair distribution of work" must also be inquired into. The researcher has to investigate on the issue as it may serve as antecedent to workplace bullying. Unfair distribution of work in its common and natural sense may invite dissatisfaction among nurses assigned to perform great volume of jobs compared to one with the same job description but performing lesser job requirements. This has also implication on merit system and accurate measurement of results based performance appraisal.

4) Prevention is better than a cure. Workplace bullying is an organizational pathology. Periodic and accurate prognosis is necessary to prevent its emergence. Prevention saves the organization precious manpower resources.

\section{References}

[1] Osborne, D. (1993) Reinventing Government. Public Product. Management Review, 349-356.

[2] Koch, M.J. and McGrath, R.G. (1996) Improving Labor Productivity: Human Resource Management Policies Do Matter. Strategic Management Journal, 17, 335-354. https://doi.org/10.1002/(SICI)1097-0266(199605)17:5<335::AID-SMJ814>3.0.CO;2-R

[3] Lu, Y. and Ramamurthy, K. (2011) Understanding the Link between Information Technology Capability and Organizational Agility: An Empirical Examination. Mis Q., 931-954.

[4] Salin, D. (2003) Ways of Explaining Workplace Bullying: A Review of Enabling, Motivating and Precipitating Structures and Processes in the Work Environment. Human Relations, 56, 1213-1232. https://doi.org/10.1177/00187267035610003

[5] Yang, L.-Q., Caughlin, D.E., Gazica, M.W., Truxillo, D.M. and Spector, P.E. (2014) Workplace Mistreatment Climate and Potential Employee and Organizational Outcomes: A Meta-Analytic Review from the Target's Perspective.

[6] Miller, J.G. and Miller, J.L. (1991) A Living Systems Analysis of Organizational Pathology. Systems Research and Behavioral Science, 36, 239-252. https://doi.org/10.1002/bs.3830360402

[7] Ayoko, O.B., Callan, V.J. and Härtel, C.E. (2003) Workplace Conflict, Bullying, and Counterproductive Behaviors. International Journal of Organizational Analysis, 11, 283-301. https://doi.org/10.1108/eb028976

[8] Berry, P.A., Gillespie, G.L., Gates, D. and Schafer, J. (2012) Novice Nurse Productivity Following Workplace Bullying. Journal of Nursing Scholarship, 44, 80-87. https://doi.org/10.1111/j.1547-5069.2011.01436.x

[9] Simons, S.R. and Mawn, B. (2010) Bullying in the Workplace-A Qualitative Study of Newly Licensed Registered Nurses. AAOHN Journal, 58, 305-311. https://doi.org/10.3928/08910162-20100616-02 
[10] Murray, J.S. (2009) Workplace Bullying in Nursing: A Problem That Can't Be Ignored. MEDSURG Nursing, 18, 273.

[11] Sheehan, M. (1999) Workplace Bullying: Responding with Some Emotional Intelligence. International Journal of Manpower, 20, 57-69. https://doi.org/10.1108/01437729910268641

[12] Okechukwu, C.A., Souza, K., Davis, K.D. and de Castro, A.B. (2014) Discrimination, Harassment, Abuse, and Bullying in the Workplace: Contribution of Workplace Injustice to Occupational Health Disparities. American Journal of Industrial Medicine, 57, 573-586. https://doi.org/10.1002/ajim.22221

[13] Folkman, S. (2013) Stress: Appraisal and Coping. Springer, Berlin.

[14] DeLongis, A., Folkman, S. and Lazarus, R.S. (1988) The Impact of Daily Stress on Health and Mood: Psychological and Social Resources as Mediators. Journal of Personality and Social Psychology, 54, 486. https://doi.org/10.1037/0022-3514.54.3.486

[15] Hill, M. (2014) Policy Process: A Reader. Routledge.

[16] Hoel, H. and Salin, D. (2003) 10 Organisational Antecedents of Workplace Bullying. Bullying Emot. Abuse Workplace 2003.

[17] Hutchinson, M. and Jackson, D. (2015) The Construction and Legitimation of Workplace Bullying in the Public Sector: Insight into Power Dynamics and Organisational Failures in Health and Social Care. Nursing Inquiry, 22, 13-26. https://doi.org/10.1111/nin.12077

[18] American Nurses Association (2001) Code of Ethics for Nurses with Interpretive Statements. Nursesbooks.org.

[19] Gabriel, A.G. and Gabriel, J.P. (2016) Basic Education Teachers and Workplace Bullying in the Philippines: An Organizational Prism. Imperial Journal of Interdisciplinary Research, 2, 2150-2156. http://www.imperialjournals.com/index.php/IJIR/article/view/2469/2373

[20] Williams, K.D., Forgas, J.P. and Von Hippel, W. (2005) The Social Outcast: Ostracism, Social Exclusion, Rejection, and Bullying. Psychology Press.

[21] Liu, H. and Xia, H. (2016) Workplace Ostracism: A Review and Directions for Future Research. Journal of Human Resource and Sustainability Studies, 4, 197. https://doi.org/10.4236/jhrss.2016.43022

[22] Zhao, H., Peng, Z. and Sheard, G. (2013) Workplace Ostracism and Hospitality Employees' Counterproductive Work Behaviors: The Joint Moderating Effects of Proactive Personality and Political Skill. International Journal of Hospitality Management, 33, 219-227.

[23] Hoel, H., Glasø, L., Hetland, J., Cooper, C.L. and Einarsen, S. (2010) Leadership Styles as Predictors of Self-Reported and Observed Workplace Bullying. British Journal of Management, 21, 453-468.

[24] Curtis, M. and Curtis, M. (2008) Great Political Theories V. 2: A Comprehensive Selection of the Crucial Ideas in Political Philosophy from the French Revolution to Modern Times. Harper Collins.

[25] Andres, T.D. (1981) Management by Filipino Values: A Sequel to Understanding Filipino Values. Quezon City, New Day Publ. 17.

[26] Harvey, M., Treadway, D., Thomson, J. and Duke, A. (2009) Bullying in the $21^{\text {st }}$ Century Global Organization: An Ethical Perspective. Journal of Business Ethics, 85, 27. Springer Link. https://link.springer.com./article/10.1007/s10551-008-9746-8 
[27] Milam, A.C., Spitzmueller, C. and Penney, L.M. (2009) Investigating Individual Differences among Targets of Workplace Incivility. Journal of Occupational Health Psychology, 14, 58. https://doi.org/10.1037/a0012683

[28] Sperry, L. (2009) Mobbing and Bullying: The Influence of Individual, Work Group, and Organizational Dynamics on Abusive Workplace Behavior. Consulting Psychology Journal: Practice and Research, 61, 190. https://doi.org/10.1037/a0016938

Submit or recommend next manuscript to SCIRP and we will provide best service for you:

Accepting pre-submission inquiries through Email, Facebook, LinkedIn, Twitter, etc. A wide selection of journals (inclusive of 9 subjects, more than 200 journals) Providing 24-hour high-quality service User-friendly online submission system Fair and swift peer-review system Efficient typesetting and proofreading procedure Display of the result of downloads and visits, as well as the number of cited articles Maximum dissemination of your research work

Submit your manuscript at: http://papersubmission.scirp.org/

Or contact jss@scirp.org 